\title{
A Study of Leadership Style and Learning Organization in Canadia Bank Plc, Phnom Penh, Cambodia
}

\author{
Sopheak LANG \\ Graduate School of Public Administration, Burapha University \\ Email: langsopheak@yahoo.com
}

\begin{abstract}
This study aimed to: (1) explore leadership styles in Canadia Bank Plc based on Bass's model (1985), (2) discover perceptions of staff towards the level of learning organization in the bank, and (3) investigate whether department managers' leadership styles have significant impact on dimensions of learning organization. This study was based on Watkins and Marsick's model and Bass's theory so as to explore the level of learning organization and leadership styles. The data were collected from 168 staff working in the bank head office by administering questionnaire, and were analyzed by descriptive statistics and inferential statistics (multiple regression). The findings revealed that leadership styles in the bank were transformational and transactional leadership. However, transformational leadership was practiced more often than transactional leadership. The level of learning organization in the bank was at "often" level. The study further revealed that transactional leadership had more influence in cultivating learning organization than transformational leadership.
\end{abstract}

Keywords: Transformational Leadership, Transactional Leadership, Learning Organization, Candadia Bank Plc

\section{Introduction}

As the upcoming of ASEAN Economic Community (AEC) in 2015, all member countries will be integrated into one trade bloc. Individual members will increase their potential through the enhancement of labor market, advantages of competitive products and human capital. In order to survive in such changing environment, Canadia Bank Plc, one of famous financial institutes in Cambodia, has to learn continuously more than it has ever done before. That requires the bank to become learning organization. However, creating a learning organization is a difficult task that only leader who is at the top of the hierarchy has ability to do. It is consistent with Senge (1990) who said that leadership plays crucial roles in facilitating employees' learning organization.

\section{Literature Review}

Over preview of literature, different authors had different views of leadership style and have categorized leadership in different kinds. However, based on Bass (1985), leadership styles were comprised of transformational and transactional leadership. Furthermore, dimensions of Learning Organization Questionnaire (DLOQ) are created by Watkins and Marsick (2003) in order to clearly define level of learning organization in any organization. Seven complementary action imperatives of learning organization are continuous learning, inquiry and dialogue, collaboration and team learning, systems to share and capture learning, empowering people, connecting the organization, and strategic leadership for learning.

\section{Methodology}

This research was quantitative research. According to sampling formula of Taro Yamane, 168 out of 289 staff in different 31 departments in head office of the bank was selected as the sample size. Then Stratified Random Sampling was employed to find the sample size in individual departments. There were two sets of questionnaire using in this study: Multi-Leadership Questionnaire (MLQ), and Dimensions of Learning Organization Questionnaire (DLOQ) by Watkins and Marsick (2003). Each item of the two questionnaires was rated by using a five-point Likert scale, ranging from never (1) to always (5). The data obtaining from MLQ and DLOQ questionnaire were analyzed by multiple regression to study the impact of the leadership styles towards the dimensions of learning organization. The collected data were processed and analyzed by statistical program for social analysis.

\section{Results}

The findings are arranged orderly according to the research questions. 
Question \#1: Which leadership styles are being practiced in Canadia Bank Plc?

\begin{tabular}{lccc}
\hline \multicolumn{1}{c}{ Leadership Styles } & Mean & SD & Level of Frequency \\
\hline Transformational leadership & 3.80 & 0.22 & Often \\
Transactional leadership & 3.40 & 0.16 & Sometimes \\
\hline
\end{tabular}

Table 1 Descriptive Statistics of the Leadership Styles

Table 1 demonstrates subordinates' reaction towards managers' leadership styles being practiced in the head office of the bank. Transformational leadership was at often level $(\bar{X}=3.80 ; \mathrm{SD}=0.22)$ while transactional leadership was at sometimes level $(\bar{X}=3.40$; $\mathrm{SD}=0.16)$. Though the two leadership styles Question \#2: What is the level of learning organization being perceived by the Canadia Bank's staff were rated at different level, their $\bar{X}$ values are not so different from each other. Therefore, it can be interpreted that the department managers use the two different leadership styles interchangeably according to situation in which the managers have to deal with.

\begin{tabular}{|c|c|c|c|c|}
\hline Learning organization dimensions & Descriptive Statistics & Mean & SD & $\begin{array}{l}\text { Level of } \\
\text { Frequency }\end{array}$ \\
\hline Continuous learning & & 3.43 & 0.39 & Often \\
\hline Inquiry and dialogue & & 3.34 & 0.13 & Sometimes \\
\hline Collaboration and team learning & & 3.55 & 0.27 & Often \\
\hline Systems to capture and share learning & & 3.59 & 0.08 & Often \\
\hline Empowering people & & 3.39 & 0.07 & Sometimes \\
\hline Connecting the organization & & 3.46 & 0.14 & Often \\
\hline Strategic leadership for learning & & 3.57 & 0.08 & Often \\
\hline Total & & 3.47 & 0.21 & Often \\
\hline
\end{tabular}

Table 2 Descriptive statistics of the seven dimensions of Learning Organization

According to table 2, the total average value of learning organization was at often level $(\bar{X}=3.47$; SD $=0.21)$. This can be Question \#3: Do department managers' leadership styles have a significant impact on learning organization in the bank? concluded that the bank was rated as a learning organization at high level.

\begin{tabular}{|c|c|c|c|c|c|c|}
\hline \multicolumn{7}{|c|}{ Coefficients $^{\mathrm{a}}$} \\
\hline & \multirow[t]{2}{*}{ Model } & Unstanc & Coefficients & $\begin{array}{c}\text { Standardized } \\
\text { Coefficients }\end{array}$ & \multirow[b]{2}{*}{$\mathrm{t}$} & \multirow[b]{2}{*}{ Sig. } \\
\hline & & B & Std. Error & Beta & & \\
\hline \multirow[t]{3}{*}{1} & (Constant) & .618 & .261 & & 2.367 & .019 \\
\hline & Transformational & .252 & .082 & .213 & 3.055 & .003 \\
\hline & Transactional & .542 & .069 & .545 & 7.816 & .000 \\
\hline
\end{tabular}

a. Dependent Variable: Continuous Learning $\quad$ b. Significant level of 0.05

Table 3 Regression equation of continuous learning

Equation 1: Continuous Learning $=0.618$ +0.252 transformational +0.542 transactional

The equation shows a positive relation between transformational leadership, transactional leadership, and continuous 
Coefficients $^{\mathrm{a}}$

\begin{tabular}{|c|c|c|c|c|c|c|}
\hline & \multirow[t]{2}{*}{ Model } & \multicolumn{2}{|c|}{ Unstandardized Coefficients } & \multirow{2}{*}{$\begin{array}{c}\begin{array}{c}\text { Standardized } \\
\text { Coefficients }\end{array} \\
\text { Beta } \\
\end{array}$} & \multirow[b]{2}{*}{$\mathrm{t}$} & \multirow[b]{2}{*}{ Sig. } \\
\hline & & B & Std. Error & & & \\
\hline \multirow[t]{3}{*}{1} & (Constant) & .733 & .266 & & 2.756 & .007 \\
\hline & Transformational & .185 & .084 & .158 & 2.203 & .029 \\
\hline & Transactional & .557 & .071 & .566 & 7.888 & .000 \\
\hline
\end{tabular}

a. Dependent Variable: Inquiry and Dialogue b. Significant level of 0.05

Table 4 Regression equation of inquiry and dialogue

Equation 2: Inquiry and Dialogue = $0.733+0.185$ transformational +0.557 transactional

The equation indicates a positive relation between transformational leadership, transactional leadership, and inquiry and dialogue. Transactional by a coefficient of 0.557 and transformational by a coefficient of 0.185 are said to predict inquiry and dialogue positively.

\begin{tabular}{|c|c|c|c|c|c|c|}
\hline \multicolumn{7}{|c|}{ Coefficients $^{a}$} \\
\hline & \multirow[t]{2}{*}{ Model } & Unstanda & Loefficients & Standardized & \multirow[b]{2}{*}{$\mathrm{t}$} & \multirow[b]{2}{*}{ Sig. } \\
\hline & & B & Std. Error & Beta & & \\
\hline \multirow[t]{3}{*}{1} & (Constant) & 1.031 & .276 & & 3.738 & .000 \\
\hline & Transformational & .160 & .087 & .135 & 1.835 & .068 \\
\hline & Transactional & .560 & .073 & .561 & 7.633 & .000 \\
\hline
\end{tabular}

a. Dependent Variable: Collaboration and Team learning

b. Significant level of 0.05

Table 5 Regression equation of collaboration \& team learning

Equation 3: Collaboration and Team learning $=1.031 \neq 0.160$ transformational +0.560 transactional

The equation indicates a positive relation between transactional leadership, and collaboration \& team learning. Transactional by a coefficient of 0.560 is said to predict collaboration \& team learning positively.

Coefficients $^{\mathrm{a}}$

\begin{tabular}{llccccc}
\hline \multirow{2}{*}{ Model } & \multicolumn{2}{c}{ Unstandardized Coefficients } & \multicolumn{2}{c}{$\begin{array}{c}\text { Standardized } \\
\text { Coefficients }\end{array}$} & t & Sig. \\
\cline { 3 - 5 } & & $\mathrm{B}$ & Std. Error & Beta & & .1 .054 \\
\hline 1 & (Constant) & -.305 & .290 & & .293 \\
& Transformational & .458 & .091 & .318 & 5.002 & .000 \\
& Transactional & .631 & .077 & .521 & 8.202 & .000 \\
\hline
\end{tabular}

a. Dependent Variable: System to capture learning

b. Significant level of 0.05

Table 6 Regression equation of systems to capture learning

Equation 4: Systems to capture learning $=-0.305+0.458$ transformational +0.631 transactional

The equation indicates a positive relation between transformational leadership, transactional leadership, and systems to capture learning. Transformational by a coefficient of 0.458 and transactional by a coefficient of 0.631 are said to predict systems to capture learning positively.

\begin{tabular}{|c|c|c|c|c|c|c|}
\hline \multicolumn{7}{|c|}{ Coefficients $^{\mathrm{a}}$} \\
\hline & \multirow[t]{2}{*}{ Model } & Unstand & Coefficients & Standardized & \multirow[b]{2}{*}{$\mathrm{t}$} & \multirow[b]{2}{*}{ Sig. } \\
\hline & & $\mathrm{B}$ & Std. Error & Beta & & \\
\hline \multirow[t]{3}{*}{1} & (Constant) & .026 & .300 & & .086 & .932 \\
\hline & Transformational & .414 & .095 & .307 & 4.369 & .000 \\
\hline & Transactional & .532 & .080 & .460 & 6.559 & .000 \\
\hline
\end{tabular}

a. Dependent Variable: Empowering people

b. Significant level of 0.05

Table 7 Regression equation of empowering people 
Equation 5: Empowering people $=0.026$ +0.414 transformational +0.523 transactional

The equation indicates a positive relation between transformational leadership, transactional leadership, and empowering people. Transformational by a coefficient of 0.414 and transactional by a coefficient of 0.523 are said to predict empowering people positively.

\begin{tabular}{|c|c|c|c|c|c|c|}
\hline \multicolumn{7}{|c|}{ Coefficients $^{\mathrm{a}}$} \\
\hline & \multirow[t]{2}{*}{ Model } & Unstand & oefficients & $\begin{array}{l}\text { Standardized } \\
\text { Coefficients }\end{array}$ & \multirow[b]{2}{*}{$\mathrm{t}$} & \multirow[b]{2}{*}{ Sig. } \\
\hline & & $\mathrm{B}$ & Std. Error & Beta & & \\
\hline \multirow[t]{3}{*}{1} & (Constant) & .363 & .278 & & 1.305 & .194 \\
\hline & Transformational & .308 & .088 & .242 & 3.508 & .001 \\
\hline & Transactional & .566 & .074 & .529 & 7.651 & .000 \\
\hline
\end{tabular}

a. Dependent Variable: Connecting the organization

b. Significant level of 0.05

Table 8 Regression equation of connecting the organization

Equation 6: Connecting the organization $=0.363+0.308$ transformational +0.566 transactional

The equation indicates a positive relation between transformational leadership, transactional leadership, and connecting the organization. Transformational by a coefficient of 0.308 and transactional by a coefficient of 0.566 are said to predict connecting the organization positively.

Coefficients $^{\mathrm{a}}$

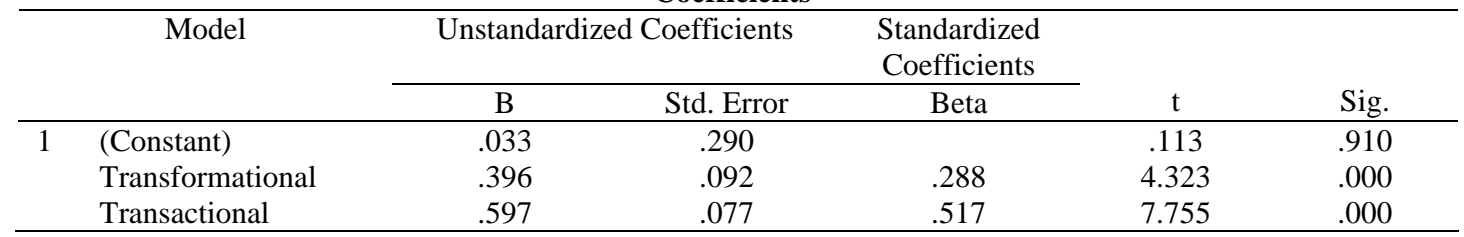

a. Dependent Variable: Strategic leadership for learning

b. Significant level of 0.05

Table 9 Regression equation of strategic leadership for learning

Equation 7: Strategic leadership for learning $=0.033+0.396$ transformational + 0.597 transactional

The equation shows a positive relation between transformational leadership, transactional leadership, and strategic leadership for learning. Transformational by a coefficient of 0.396 and transactional by a coefficient of 0.597 are said to predict strategic leadership for learning positively.

\section{Discussion}

The finding shows that transformational leadership has an influence on the six dimensions of learning organization except "collaboration \& team learning” dimension, while transactional leadership has an influence on all the seven dimensions of learning organization. This result is somehow consistent with the prior studies (Rijal,2010; Martinettes, 2002; Singh, 2008; Pimapunsri 2009) who found that leadership styles influence the dimensions of learning organization. Additionally, the current study found an interesting result that transactional leadership has more profound influence in cultivating a learning organization than transformational leadership. Transactional leader plays more important roles in cultivating the bank as a learning organization than transformational leader due to two significant reasons. First, referring to Maslow's hierarchy of needs theory, it is believed that transactional leader elevates followers' need up to the thirdlevel of the hierarchy of need $\left(1^{\text {st }}\right.$ food, $2^{\text {nd }}$ Safety, and $3^{\text {rd }}$ love and belonging); while transformational leader raises the needs of followers up to the highest level of need of Maslow (Daft, 2008). As Cambodia is a developing country, the employees' job satisfaction is under limited. For most of them, being able to reach the third level is enough for them. Thus, one can assume that transactional leadership is the most applicable in Cambodia context, since this type of leadership could help provide their followers what they desire. Second, according to theory $\mathrm{X}$ and $\mathrm{Y}$ of McGregor, managers assumes that $\mathrm{X}$ employees must be controlled, directed or threatened to get them to put forth their best effort. This type of employee suits best with transactional leader who is likely to take control the staff's performance by providing rewards or punishment according to adequacy 
of their performance (Burn, 1978). Therefore, the bank may need transactional skills to control the staff's performance. To conclude, transformational and transactional leadership are seen to be practiced in the bank; however, transactional leadership is the more-effective one in promoting the bank as a learning organization.

\section{Recommendation}

This research expands the literature on leadership styles and their relationship to learning organization in the context of Canadia bank and the other banks having similar background with Canadia bank. The findings discovered that transactional leaders have more influence in cultivating a learning organizational environment than transformational leaders do. This suggests that learning organization should shift the focus of leadership training to transactional leadership skill training. Also, these results can aid human resource managers in their training and/or the selection process.

\section{Acknowledgement}

The author of this article wishes to offer his sincere gratitude to my research advisors Dr. Ritthikorn Siriprasertchok and Dr. Thanawat Pimoljonda for their kind support, valuable advice and guidance to complete this research. He also extends special thank to Dr. Karen E, Watkins for her granting permission for using the DLOQ in this Master's degree project.

\section{References}

[1] Bass, B. M. (1985). Leadership and performance beyond expectations. New York: Free Press.

[2] Daft, L. R. (2008). Leadership (5th ed.). Andover: Cengage Learning.

[3] Martinette, V. C. (2002). Learning Organizations and Leadership Style. National Fire Academy. Retrieved $14^{\text {th }}$ July, 2012, from www.usfa.fema.gov/ downloads/pdf/tr_02cm.pdf.

[4] Mahseredjian, A., Karkoulian, S., \& Messarra, L. (2011). Leadership styles correlate of learning organization in a nonwestern culture. The business review, Cambridge, 17(2), 269-227.

[5] Pimapunsri, P. (2009). Learning organization and leadership style in the Thai Hotel industry. Unpublished doctoral dissertation, Burapha University, Thailand.
[6] Senge, P. M. (1990). The fifth discipline : the art and practice of the learning organization. New York: Doubleday/ Currency.

[7] Watkins, K., \&Marsick, V. (1997). Dimensions of the learning organization questionnaire. Warwick, RI: Partners for the Learning Organization. Reprinted in Marsick, V., \& Watkins, K. (2003). Demonstrating the value of an organization's learning culture: The dimensions of the learning organization questionnaire. Advances in Developing Human Resources, 5(2), 132-151. 